\title{
Fluorescence Modulation by Fast Photochromism of [2.2]Paracyclophane-Bridged Imidazole Dimer Possessing a Perylene Bisimide Moiety
}

\author{
Katsuya Mutoh, ${ }^{a}$ Michel Sliwa, ${ }^{b}$ Eduard Fron, ${ }^{c}$ Johan Hofkens,${ }^{c}$ and Jiro Abe ${ }^{* a}$
}

The development of single-molecule imaging and super-resolution microscopic tequniques has promoted the study of fluorescence switchable molecules that have been important for the in-depth understanding of activities of organelles and geometries of materials in nano- and microscales. The utilization of photochromic compounds as the photo-switching trigger is one of the efficient strategies to reversibly control the fluorescent "ON" and "OFF" states. In this study, we demonstrated the red-color fluorescence switching of a perylene bisimide (PBI) derivative by using the fast photochromic [2.2]paracyclophanebridged imidazole dimer. The transient colored biradical species as the fluorescence quencher is generated upon UV light irradiation. Because the biradical species has broad absorption bands in the whole visible light and the near-infrared regions (500-900 nm), the fluorescence of PBI could be efficiently quenched by Förster resonance energy transfer (FRET). The fluorescence intensity was switched by the fast photochromic cycles within a few tens of milliseconds. The potential capability of the transient biradical species to switch the fluorescence in the visible and NIR regions will open up the multicolor fluorescence imaging.

\section{Introduction}

Considerable attention has been paid to the fluorescence microscopy because of the convenience and useful characteristic to clarify structures and activities of organelles, active sites of inorganic catalysts and conformations of polymer materials. ${ }^{1-5}$ From the discovery of the green fluorescent protein (GFP), many kinds of fluorescent switchable proteins and artificial organic probes have been developed in biochemistry. 6,7 Photoswitchable fluorescent probes are useful to observe a specific structure only under light irradiation with small background noise and to track movement and transportation of materials. The development of organic fluorescent probes has been also required for the definitive analysis of biological activities because the introduction of fluorescent proteins with large molecular weight often disturbs characteristic target features. ${ }^{8-10}$

On the other hand, the spatial resolution of fluorescence microscopy is limited to the half of the emission wavelength in principle, which is known as the optical diffraction limit. Recently, to overcome the optical diffraction limit, superresolution microscopies such as stimulated-emission depletion (STED) microscopy, ${ }^{11,12}$ light switching microscopy (RESOLFT type microscopy) ${ }^{13,14}$ and photoactivated localization microscopy (PALM)/stochastic optical reconstruction microscopy (STORM) $)^{15-18}$ were reported. By using these spectroscopic techniques, nanometric detail structures of cell organelles have been revealed in a stream. ${ }^{19}$ Super-resolved techniques were in some cases disregarded as they were subjected to photobleaching due the need of high on/off contrast. However different methods were recently develop like MINFLUX ${ }^{20}$ or optical fluctuation imaging (SOFI), ${ }^{21}$ which enable background-free and contrast enhanced imaging, and facilitate to utilize temporal

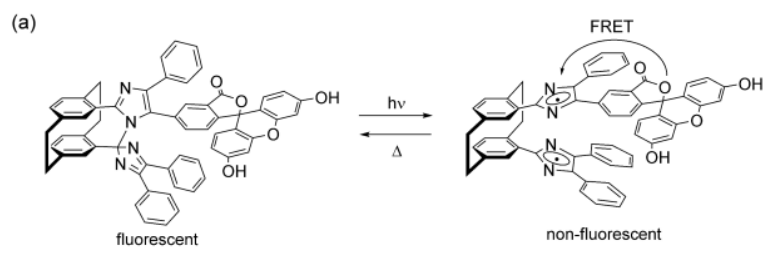

(b)
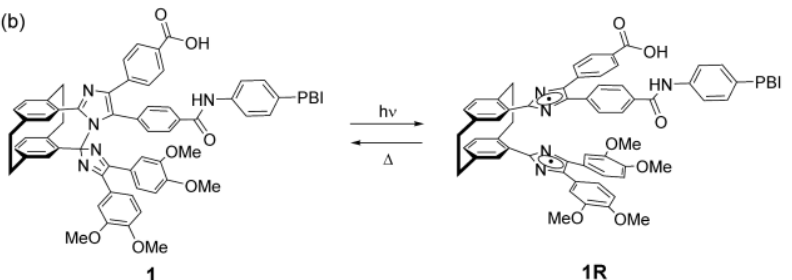

(c)
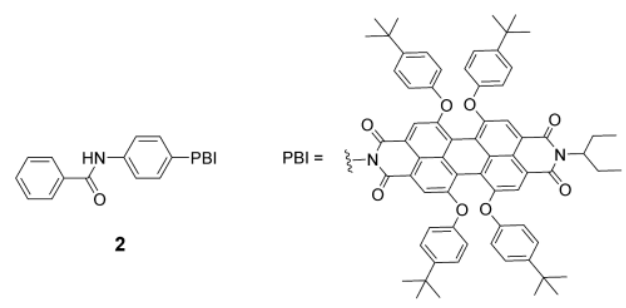

Scheme 1 Photochromic Reaction Scheme of 1. 
(a)

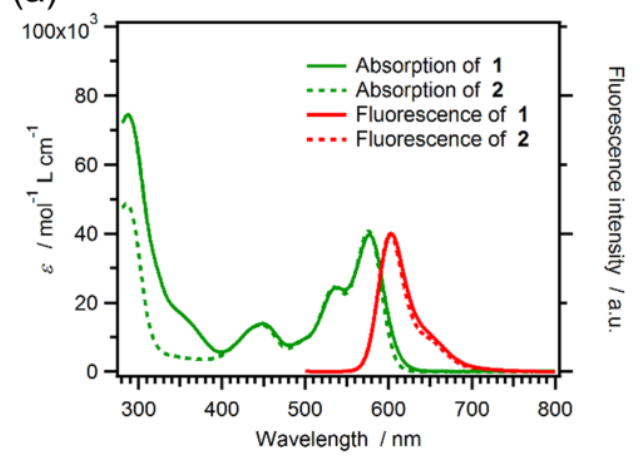

(b)

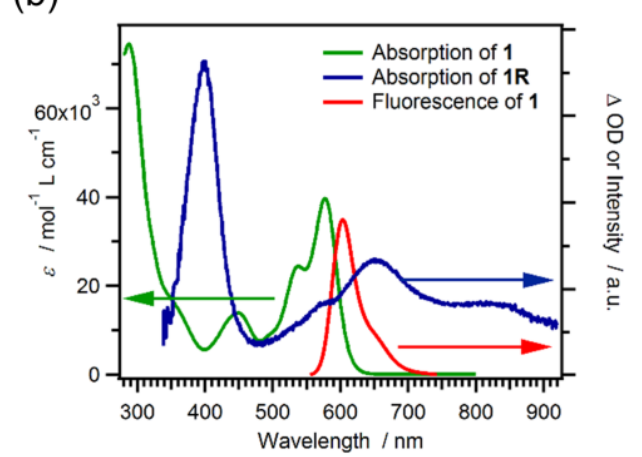

Fig. 1 (a) UV-vis absorption spectra (green) and fluorescence spectra (red) of $\mathbf{1}$ and $\mathbf{2}$ in benzene. (b) Transient vis-NIR absorption spectrum recorded just after laser excitation (blue) of 1 in degassed benzene $\left(6 \times 10^{-6} \mathrm{M}\right.$; excitation wavelength, $355 \mathrm{~nm}$; pulse width, $5 \mathrm{~ns}$; power, $3 \mathrm{~mJ} /$ pulse).

fluctuations of photo-switchable fluorescent probe. ${ }^{13}$ Therefore, the attractive fluorescence switching or fluctuating compounds have been desired from the perspecives of both fundamental studies and further applications for fluorescence imaging.

Photochromic compounds reversibly change their physical properties, absorption and fluorescence spectra, electronic and magnetic properties, and also induce the macroscopic structural changes in liquid crystal, polymer matrix and solid state upon irradiation with light. ${ }^{22-27}$ Recently, studies of fluorescence switching by using photochromism have been attracted because the drastic changes of the electronic structures of photochromic compounds are suitable to switch the fluorescence properties by an electron transfer or Förster resonance energy transfer (FRET). ${ }^{28-32}$ The [2.2]PC-bridged imidazole dimer which is one of the T-type photochromic compounds shows the fast photochromism with a high quantum yield close to unity and excellent fatigue resistance. ${ }^{33}$ The $\mathrm{C}-\mathrm{N}$ bond between the two imidazole rings is cleaved within few hundreds of femtosecond upon irradiation with UV light, resulting in the generation of the colored biradical species. Because the biradical species has broad absorption bands in the whole visible light and the near-infrared (NIR) regions (500-900 nm), fluorescence of variable fluorescent dyes can be modulated by FRET from the excited singlet state of fluorophores to the biradical species, leading to the development of the multicolor switchable fluorescence probes for super resolution images. Furthermore, focus super-resolution fluorescence microscopies such as RESOLFT which use photo-switchable systems (proteins or dyes) usually require an extra laser excitation to recover the fluorescent "ON" state from the "OFF" state. ${ }^{13}$ Fast photochromic compounds showing the thermal back reaction in millisecond time scales will allow acquiring an image at a videoframe rate without the use of any lasers to recover the "OFF" to "ON" states. We previously demonstrated the green-color millisecond fluorescence modulation with the fast photochromic bridged imidazole dimer possessing fluorescein as a green-color fluorescence unit. ${ }^{34}$ The fluorescence intensity is efficiently quenched in the biradical state by FRET from the excited state of fluorescein to the biradical species. After we have developed the fluorescence switching by the fast photochromic reaction of the bridged imidazole dimer, the applications to the super-resolution imaging by photochromic imidazole dimers have been received increased attention. ${ }^{35,36}$ While we succeeded to switch the fluorescence of fluorescein, the photostability at the single molecular level of fluorescein is only few millisecond and hinders its use for superresolution microscopies. Thus, both fluorescence switching abilities and high fluorescence quantum yield with high photostability of fluorescent probes at the single molecular level are required for applying to the super resolution microscopy. To overcome this issue, we newly designed a fluorescence switchable [2.2]PC-bridged imidazole dimer possessing a perylene bisimide (PBI) as a redcolor fluorescent unit (1, Scheme 1$)$. PBI is known as one of the more photo-stable dyes at the single molecule level with a fluorescence quantum yield about $1 .{ }^{37}$ The [2.2]PC-bridged imidazole dimer is indirectly connected with PBI unit by an amide bond 
to avoid a direct coupling that could lead to a decrease of the fluorescence quantum yield of PBI. Moreover, the sensitivity of the imidazole dimer unit to the UVA region is enhanced by the introduction of methoxy groups to achieve the efficient photochromic reaction upon UV light irradiation. ${ }^{38}$ Thus, 1 has the satisfactory properties for demonstrating the fluorescence modulation.

\section{Results and discussion}

\section{Photophysical and Photochromic Property}

Table 1 Time resolved and fluorescence quantum yield data of $\mathbf{1}$ and $\mathbf{2}$ in benzene with two different excitations wavelength.

\begin{tabular}{ccccc}
\hline$\lambda_{\text {ex }}$ & $\Phi_{1}$ & $\Phi_{2}$ & $\tau_{1}$ & $\tau_{2}$ \\
\hline \multirow{2}{*}{$360 \mathrm{~nm}$} & \multirow{2}{*}{0.21} & \multirow{2}{*}{0.50} & $0.87(7.2 \%)$ & $0.53(2.9 \%)$ \\
& & & $5.56(92.8 \%)$ & $5.73(97.1 \%)$ \\
\multirow{2}{*}{$540 \mathrm{~nm}$} & \multirow{2}{*}{0.86} & \multirow{2}{*}{0.90} & $0.69(8.1 \%)$ & $0.38(6.5 \%)$ \\
& & & $5.38(91.9 \%)$ & $5.46(93.5 \%)$ \\
\hline
\end{tabular}

Table 2 Solvent Dependence of Fluorescence Quantum Yields and Lifetimes of 1 and 2 Measured at $605 \mathrm{~nm}$ with 540-nm Light Excitation

\begin{tabular}{c|cccc}
\hline & benzene & THF & acetone & acetonitrile \\
\hline$\Phi_{1}$ & 0.86 & 0.83 & 0.70 & 0.55 \\
$\Phi_{2}$ & 0.90 & - & - & 0.92 \\
& 5.38 & 5.70 & 5.81 & 5.71 \\
& $(91.9 \%)$ & $(97.7 \%)$ & $(94.7 \%)$ & $(94.3 \%)$ \\
$\tau_{1}(\mathrm{~ns})$ & 0.69 & 0.70 & 0.87 & 0.53 \\
& $(8.1 \%)$ & $(2.3 \%)$ & $(5.3 \%)$ & $(5.7 \%)$ \\
& 5.46 & & & 6.01 \\
& $(93.5 \%)$ & & & $(96.9 \%)$ \\
$\tau_{2}(\mathrm{~ns})$ & 0.38 & - & & 0.27 \\
& $(6.5 \%)$ & & & $(3.1 \%)$ \\
$k_{\mathrm{nr} 1}$ & 2.5 & 3.0 & 5.2 & 7.9 \\
$\left(\times 10^{7} \mathrm{~s}^{-1}\right)$ & & & & \\
\hline
\end{tabular}

The steady state UV-vis absorption and fluorescence spectra of $\mathbf{1}$ are compared with those of the individual PBI unit (2, Scheme 1 and 4 ) as a reference compound (Fig. 1a). The absorption and fluorescence spectra of $\mathbf{1}$ in visible light region are similar to those of 2. On the other hand, the molar extinction coefficient of $\mathbf{1}$ in the UVA region is larger than that of $\mathbf{2}$. Because of the introduction of the electron-donating methoxy group, the [2.2]PC-bridged imidazole dimer unit of $\mathbf{1}$ has the relatively large absorption band at $350 \mathrm{~nm}$, which can be ascribed to the intramolecular charge transfer transition from the dimethoxy phenyl groups to the electronwithdrawing $4 \pi$ electron imidazole ring and that from the electron-donating $6 \pi$ electron imidazole ring to the carboxyl phenyl group. ${ }^{38}$ Thus, all in the absorption spectrum of 1 is mainly the sum of those of fluorescent (PBI) and photochromic units (bridged imidazole dimer) as expected using the amide bond spacer. The fluorescence quantum yields estimated by using cresyl violet $(\Phi=0.54 \text { in ethanol })^{39}$ as a standard for $540 \mathrm{~nm}$ light excitation and quinine sulfate $\left(\left(\Phi=0.55 \text { in } 0.5 \mathrm{M} \mathrm{H}_{2} \mathrm{SO}_{4}\right)^{40}\right.$ as a standard for 360 $\mathrm{nm}$ excitation are summarized in Table 1. The quantum yield of 2 with $360 \mathrm{~nm}$ excitation is approximately half of that with $540 \mathrm{~nm}$ excitation. Fluorescence emission decays measured at $605 \mathrm{~nm}$ by single photon counting method for 2 excited at $540 \mathrm{~nm}$ and 365 $\mathrm{nm}$ give two time constants by fitting the decay with a double exponential equations (Table 1, Fig. SXX, ESI + ), a few hundred of picosecond one (minor contribution less than 10\%) and a $5.5 \mathrm{~ns}$ contribution (more than 90\%). These time constants are in agreement with the literature, the short component is link to interconversion between two conformational arrangements of substituents at the bay. ${ }^{41}$ Therefore the decrease of fluorescence quantum yield for $\mathbf{2}$ with $360 \mathrm{~nm}$ excitation is due to a fast internal conversion directly to the ground state in competition to the relaxation to the S1 state. On the other hand, although there is no significant difference in the fluorescence quantum yield between $\mathbf{1}$ and $\mathbf{2}$ upon $540 \mathrm{~nm}$ excitation, the fluorescence quantum yield with $360 \mathrm{~nm}$ excitation of $\mathbf{1}$ is largely decreased, compared with that of $\mathbf{2}$. The fluorescence excitation spectra of $\mathbf{1}$ and $\mathbf{2}$ are similar in the whole region (Fig. S11, ESI + ), indicating that the bridged imidazole dimer and PBI units are not conjugated. In addition, the picosecond fluorescence decays of 1 do not show any changes between 360 and $540 \mathrm{~nm}$ excitation (Table 1, Fig. SXX, ESI + ), 


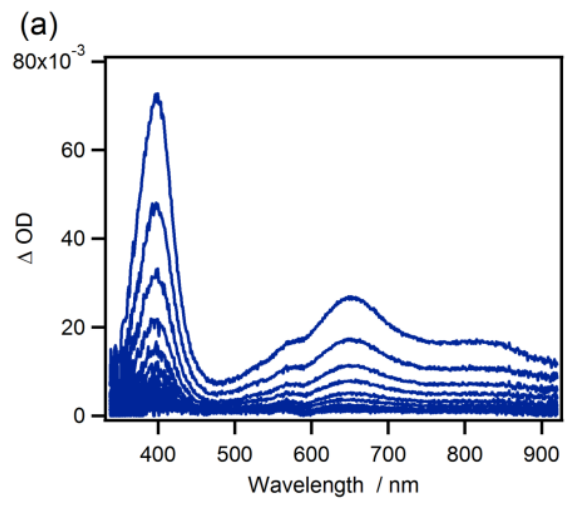

(b)

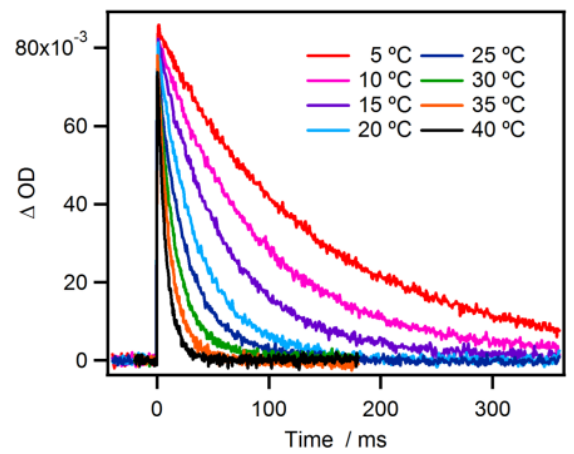

Fig. 2 (a) Transient vis-NIR absorption spectra of $\mathbf{1}$ in degassed benzene at 25 ${ }^{\circ} \mathrm{C}\left(6 \times 10^{-6} \mathrm{M} ; 10 \mathrm{~mm}\right.$ light path length). Each of the spectra was recorded at $10 \mathrm{~ms}$ intervals after excitation with a nanosecond laser pulse (excitation wavelength, $355 \mathrm{~nm}$; pulse width, $5 \mathrm{~ns}$; power, $3 \mathrm{~mJ} /$ pulse). (b) Decay profiles of the colored species generated from 1 , monitored at $400 \mathrm{~nm}$ in degassed benzene $\left(6 \times 10^{-6} \mathrm{M}\right)$.

the decrease of the fluorescence quantum yield of $\mathbf{1}$ with $360 \mathrm{~nm}$ excitation, compared with that of $\mathbf{2}$, is due to the relatively-large absorption of the [2.2]PC-bridged imidazole dimer unit and the ultrafast formation of the transient biradical within a few hundreds of femtosecond upon UV light irradiation. ${ }^{42}$ The large molar extinction coefficient of the imidazole dimer unit is suitable for enhancing the efficiency of the photochromic reaction to produce the biradical species upon UV light irradiation.

The dependence of the fluorescence quantum yields of 1 on the solvent polarity were investigated in detail (Table 2). The fluorescence quantum yield of $\mathbf{1}$ has the negative correlation with the solvent polarity and decreases in the polar solvent while that of $\mathbf{2}$ does not show any dependence on the polarity of the solvent. This solvent dependence of the quantum yields suggests the possibility of the electron transfer process from PBI unit to the imidazole dimer unit by the irradiation of 540-nm light. To reveal the origin of the solvent dependence, the fluorescence lifetime measurement in several solvent conditions was performed by the time-correlated single photon counting (Table 2 and Fig. S12, ESI + ). The main long component of the two decay components of the fluorescence lifetime of $\mathbf{1}$ slightly increase in the polar solvent. Because the charge-separated state resulting from the electron transfer is stabilized in polar solvent, the efficiency of the electron transfer is generally increased in polar solvent, leading to the decrease of the life-time of fluorescence by increasing the polarity of the solvent. Thus, the electron transfer process from the PBI unit to the [2.2]PC-bridged imidazole dimer is not appropriate. On the other hand, because the fluorescence quantum yield 
(a)

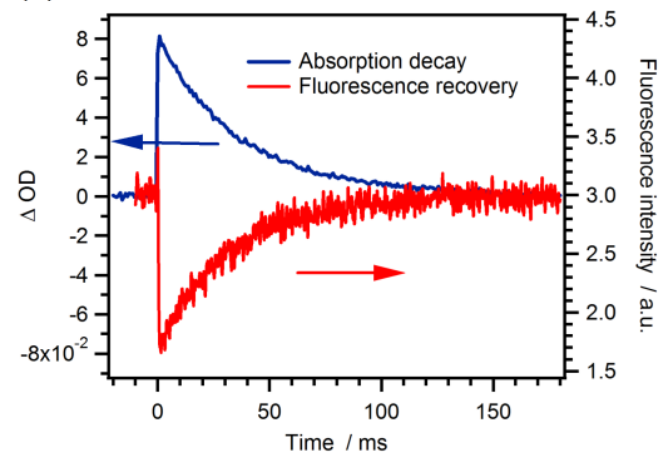

(b)

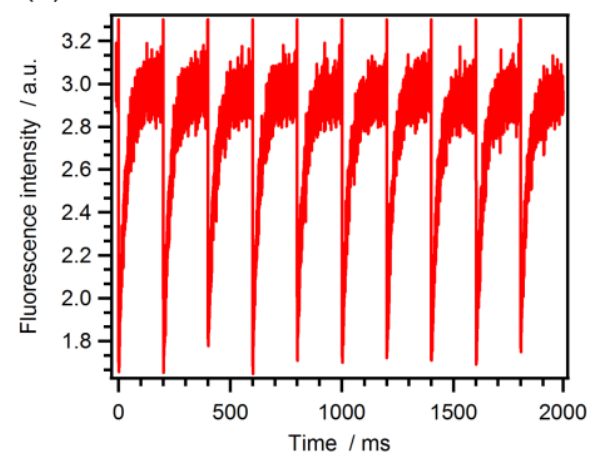

Fig. 3 (a) Time profile of the transient absorbance at $400 \mathrm{~nm}$ and fluorescence intensity at $605 \mathrm{~nm}\left(20^{\circ} \mathrm{C}\right.$ in benzene, $540 \mathrm{~nm}$ excitation) after $355 \mathrm{~nm}$ laser excitation (pulse width, $4 \mathrm{~ns}$; power, $10 \mathrm{~mJ} /$ pulse). (b) Fluorescence switching cycles upon $355 \mathrm{~nm}$ laser excitation.

of $\mathbf{2}$ is not affected by the polarity of solvent, the decrease in the fluorescence quantum yield of $\mathbf{1}$ in the polar solvent can be described as the result of the increase in the non-radiative relaxation rate by attaching the imidazole dimer unit to PBI. The nonradiative relaxation rate constant is defined as eq. 1

$$
k_{n r}=\frac{1}{\tau_{f}}\left(1-\Phi_{f}\right)
$$

where $\tau_{f}$ is the fluorescence life-time and $\Phi_{f}$ is the fluorescence quantum yield. The estimated non-radiative relaxation rate constants show good correlation with the dielectric constant of solvents (Table 2 and Fig. S13, ESIt). Interaction between solvent and amide group spacer for 1 could be a reason for the increase of non radiative relaxation.

Fig. $1 \mathrm{~b}$ shows the UV-vis absorption spectrum, fluorescence spectrum and vis-NIR transient absorption spectrum of 1 . The transient absorption spectrum of 1 upon UV light irradiation has a narrow absorption band at $400 \mathrm{~nm}$ and a broad absorption bands which cover the visible and NIR light regions from $500 \mathrm{~nm}$ to $900 \mathrm{~nm}$, attributing to the characteristic absorption band of the photogenerated biradical species 1R. The absorption band at around $800 \mathrm{~nm}$ is appeared by the through-space radical-radical interaction. ${ }^{43}$ Because the fluorescence spectrum largely overlaps with the absorption band of 1R, the efficient energy transfer (FRET) from the excited state of the PBI moiety to the radical species is expected. The fluorescence switching behavior with the fast photochromic reaction is discussed later.

All of the absorption bands of $\mathbf{1} \mathbf{R}$ decay with the same time constant (Fig. 2a). The half-life of $\mathbf{1 R}$ is estimated to be $19 \mathrm{~ms}$ at $25^{\circ} \mathrm{C}$ in benzene, which is similar half-life with that of the typical biradical species of the [2.2]PC-bridged imidazole dimer. ${ }^{33}$ Fig. $2 \mathrm{~b}$ shows the decay profiles of the transient absorbance at $400 \mathrm{~nm}$ of 1 , measured over the temperature range from $5{ }^{\circ} \mathrm{C}$ to $40^{\circ} \mathrm{C}$. The transient absorption dynamics obeys the first order reaction kinetics, and the activation parameters are estimated from the Eyring plots (Table S1, Fig. S14 and S15, ESI + ). The $\Delta H^{\ddagger}$ and $\Delta S^{\ddagger}$ values estimated from standard least-squares analysis of the Eyring plots are $58.3 \mathrm{~kJ} \mathrm{~mol}^{-1}$ and $-19.6 \mathrm{~J} \mathrm{~K}^{-1} \mathrm{~mol}^{-1}$, respectively. The free energy barrier $\left(\Delta G^{\ddagger}=\Delta H^{\ddagger}-\mathrm{T} \Delta S^{\ddagger}\right)$ for the thermal back reaction is $64.1 \mathrm{~kJ} \mathrm{~mol}^{-1}$ at $25^{\circ} \mathrm{C}$.

\section{Fluorescence Switching Property}

The fluorescence intensity of $\mathbf{1}$ can be switched by the UV light excitation because of the formation of $\mathbf{1 R}$ which quenches the excited singlet state of the PBI moiety by FRET. Fig. 3 shows the fluorescence switching behavior accompanied by the photochromic cycles of 1 . The fluorescence intensity was monitored at $605 \mathrm{~nm}$ under $540-\mathrm{nm}$ continuous light irradiation. To the photostationary 
state of 1 under $540-\mathrm{nm}$ continuous light irradiation ( $16 \mathrm{~mW}$ ), the nanosecond laser pulse at $355 \mathrm{~nm}$ ( $5 \mathrm{~mJ}$ ) is used to induce the photochromic reaction, resulting in the instant decrease of the fluorescence intensity. The fluorescence intensity shortly thereafter recovered to the initial intensity thermally with the similar thermal back reaction rate of $\mathbf{1 R}$ (Fig. 3a). This result indicates that the fluorescence modulation is prompted by the energy transfer between the PBI moiety and the photogenerated biradical species. This fluorescence switching can be repeated many times (Fig. 3b).
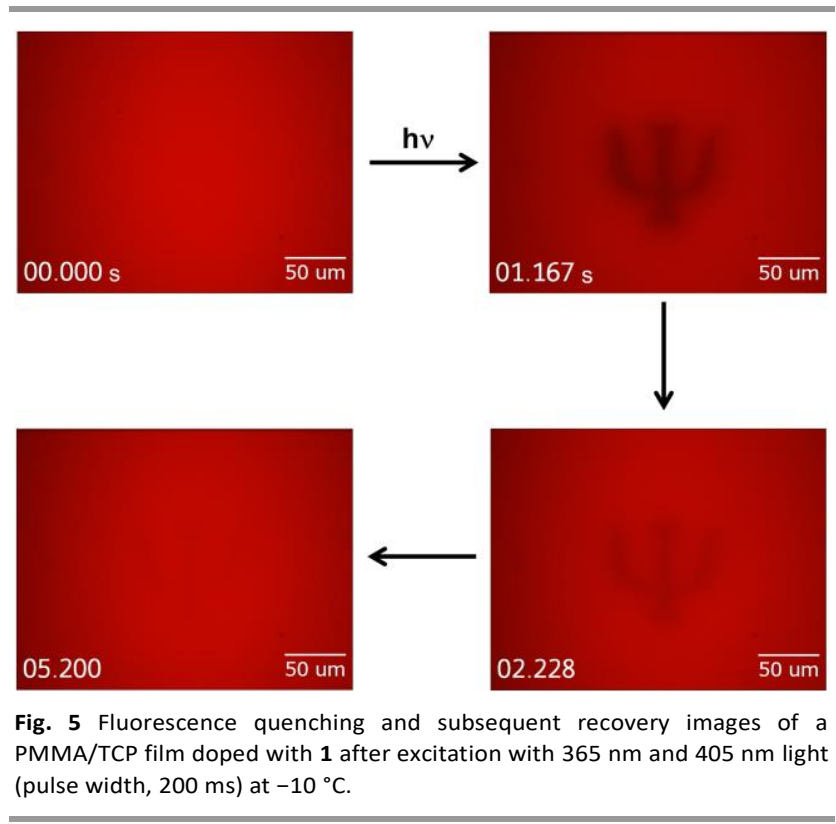

Table 3 Fluorescence Lifetimes of 1 and 2 Measured at $605 \mathrm{~nm}$ with $540-\mathrm{nm}$ Picosecond Pulse Excitation.

\begin{tabular}{c|ccc}
\hline & $\tau_{1}$ (ns) & $\tau_{2}$ (ns) & $\tau_{3}$ (ns) \\
\hline $\mathbf{1}$ & - & 0.690 & 5.381 \\
1, under 350-nm light & 0.089 & 0.927 & 5.318 \\
$\mathbf{2}$ & - & 0.379 & 5.457 \\
2, under 350-nm light & - & 0.501 & 5.500 \\
\hline
\end{tabular}

We carried out the time-correlated single photon counting to measure the time constant of FRET. Generally, the life-time of $\mathrm{S}_{1}$ state is estimated to be a few tens of picoseconds when the energy transfer process (FRET) occurs from the $\mathrm{S}_{1}$ state. ${ }^{44}$ In order to generate $\mathbf{1 R}$, the benzene solution of 1 and $\mathbf{2}$ are exposed to continuous UV light $\left(350 \mathrm{~nm}, 100 \mathrm{~mW} / \mathrm{cm}^{2}\right)$ in addition to the 540 $\mathrm{nm}$ excitation light to reach a photostationary state. The millisecond back reaction allows only to accumulate ??\% of biradical. Fig. 4 shows the fluorescence decays of 1 and 2 excited at $540 \mathrm{~nm}$ under $350 \mathrm{~nm}$ light irradiation. The two short lifetime components are obtained by UV light irradiation to the solution of $\mathbf{1}$ although the UV light exposure is almost ineffectiveness to the lifetime of the excited state of $\mathbf{2}$. The fluorescence decay curve of $\mathbf{1}$ was fitted by a three-exponential function yielding three time-constant components: the two short decay components with the lifetimes of $\tau_{1}=89 \mathrm{ps}(12.2 \%), \tau_{2}=0.927 \mathrm{~ns}(19.3 \%)$ and the long decay component with the lifetime of $\tau_{3}=5.318 \mathrm{~ns}(68.5 \%)$. The long component is similar to the typical lifetime of the $\mathrm{S}_{1}$ state of PBI as described above (Table 3). The lifetime with a few hundreds of nanosecond is also observed in the fluorescence lifetime of $\mathbf{2}$ fitted by a bi-exponential function ( $0.501 \mathrm{~ns}: 4.4 \%$ and $5.500 \mathrm{~ns}$ : $95.6 \%$ ) excited at $540 \mathrm{~nm}$ under $350 \mathrm{~nm}$ light irradiation. Thus, the short component of 1 with the lifetime of 0.927 ns would correspond to the excited state of the PBI unit irradiated by UV light. From these results, the short lifetime component with 89 ps can be attributed to the fluorescence lifetime of $1 \mathbf{R}$ in which the fluorescence of the PBI unit is quenched by the energy transfer from the $S_{1}$ state of the PBI unit to the biradical species. The FRET efficiency ( $\Phi_{\text {FRET }}$ ) is calculated to be 0.98 according to eq. 2

$$
\Phi_{\text {FRET }}=\frac{\tau}{\tau_{0}}
$$

where $\tau$ is the observed fluorescence lifetime of $\mathbf{1 R}(89 \mathrm{ps})$ and $\tau_{0}$ is that of $\mathbf{1}$ (5.318 ns). Therefore, the biradical species of bridged imidazole dimers is the efficient quencher of the excited state of PBI. It is expected that the bridged imidazole dimer can be applied to multi-color fluorescence switching probes because of the broad absorption spectrum of the biradical species in the visible and NIR regions, applicable to biological fluorescent probes. 

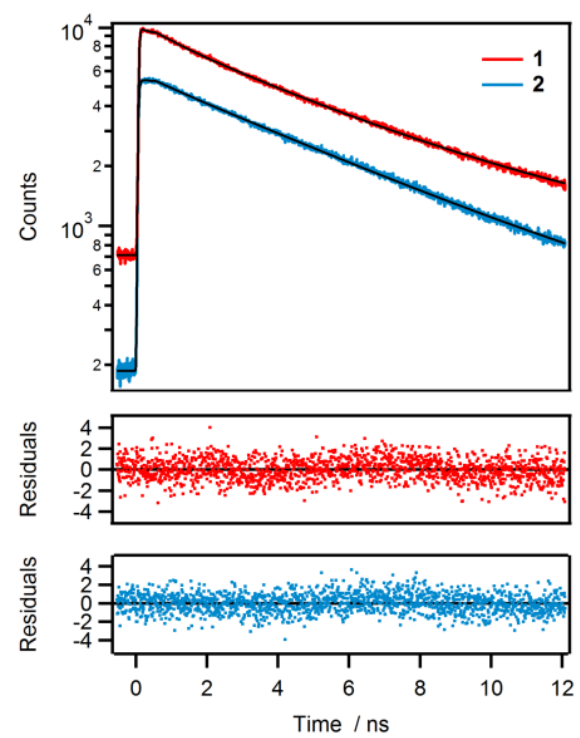

Fig. 4 Fluorescence decays of $\mathbf{1}$ and $\mathbf{2}$ under continuous $350 \mathrm{~nm}$ light irradiation measured at $605 \mathrm{~nm}$ with $540-\mathrm{nm}$ picosecond pulse excitation.

\section{Fluorescence Imaging Microscopy}

The fluorescence switching accompanied by the fast photochromism of $\mathbf{1}$ was carried out under the fluorescence microscopy as a preliminary step of the application to the super-resolution microscopy. In order to increase the on-off contrast ratio of the fluorescence, the fluorescence modulation was demonstrated at $-10{ }^{\circ} \mathrm{C}$ to reduce the rate of the thermal back reaction of $1 \mathbf{R}$ because the recovery rate (the half-life is $19 \mathrm{~ms}$ at $25^{\circ} \mathrm{C}$ ) is too large at room temperature to be detected by a common $\mathrm{CCD}$ camera. The polymer film (poly (methyl metacrylate) (PMMA)/tricresyl phosphate $(\mathrm{TCP})=2 / 3$ ) of $\mathbf{1}$ was prepared to remove the effect of the diffusion of molecules and convection of solvent. TCP is used as a plasticizer to decrease in the glass transition temperature $\left(T_{\mathrm{g}}\right)$ of the polymer because the efficiency of the photochromic reaction of [2.2]PC-bridegd imidazole dimer is reduced in the rigid polymer matrix with high $T_{\mathrm{g}} .{ }^{45}$ The millisecond thermal back reaction following a first-order reaction kinetics is clearly observed in this polymer matrix (Fig. SXX, ESI+). The irradiation with the stimulus pulse light at 365 and $405 \mathrm{~nm}$ from a high-pressure mercury vapor lamp (200 ms/pulse) induces the efficient fluorescence quenching by $\mathbf{1 R}$ under the continuous excitation with the fluorescence excitation light of $540 \mathrm{~nm}$ (Fig. 5). After the cease of the UV light radiation, the fluorescence intensity recovers rapidly within 5 seconds at $-10^{\circ} \mathrm{C}$. The contrast of the fluorescence intensity is sufficient to detect because the population of the biradical at the photostationary state is high at $-10^{\circ} \mathrm{C}$.

\section{Conclusions}

We demonstrated the rapid fluorescence switching using the photochromism of the [2.2]PC-bridged imidazole dimer possessing $\mathrm{PBI}$ as a fluorophore. The molecular design of $\mathbf{1}$ is efficient to produce the biradical species which quenches the excited state of the PBI unit by FRET upon UV light irradiation because of the high sensitivity to the UVA region derived from the intramolecular $\mathrm{CT}$ transition. The fluorescence intensity can be switched by the fast photochromic cycles within a few tens of milliseconds at room temperature. The efficiency of the energy transfer was estimated to be $98 \%$ from the fluorescence lifetime measurement. Hence, the utilization of the photochromic imidazole dimers for the fluorescence switching has a great potential for applying to the super resolution microscopy. The potential capability of the transient biradical species to switch the fluorescence in the visible and NIR regions by FRET will open up the multicolor and on-demand fluorescence imaging by the introduction of various types of fluorophores. 


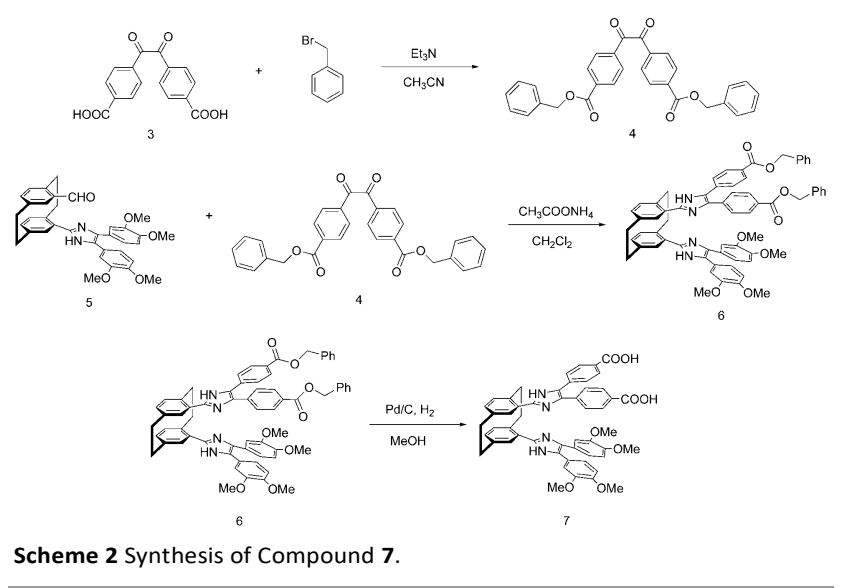

Scheme 2 Synthesis of Compound 7.

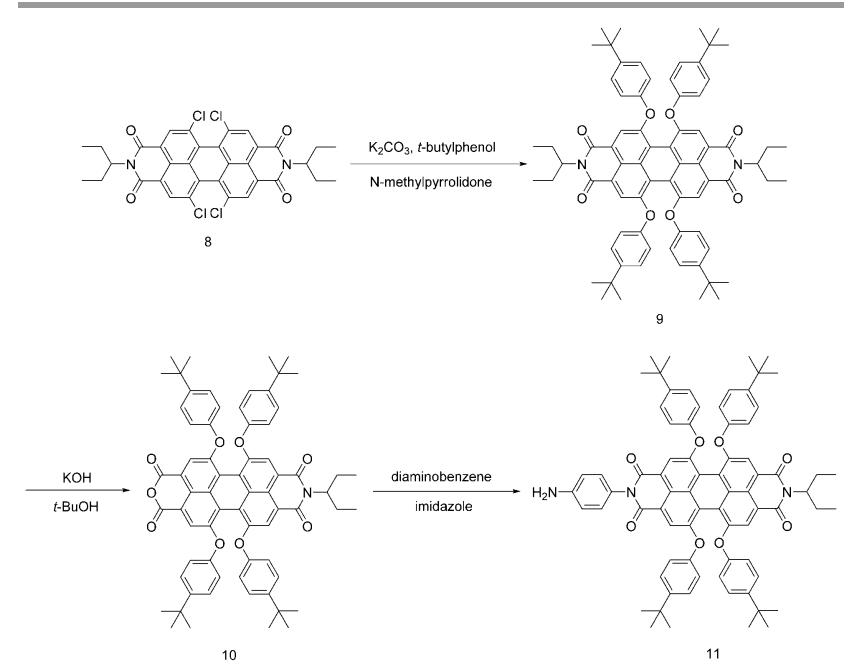

Scheme 3 Synthesis of Compound 11.

\section{Experimental section}

\section{Measurement of the Thermal Back Reaction Rate}

The laser flash photolysis experiments were carried out with a TSP-1000 time-resolved spectrophotometer (Unisoku). A $10 \mathrm{~Hz}$ Qswitched Nd:YAG (Continuum Minilite II) laser with the third harmonic at $355 \mathrm{~nm}$ (ca. $8 \mathrm{~mJ}$ per $5 \mathrm{~ns}$ pulse) was employed for the excitation light. The probe beam from a halogen lamp (OSRAM HLX64623) was guided with an optical fiber scope to be arranged in an orientation perpendicular to the exciting laser beam. The probe beam was monitored with a photomultiplier tube (Hamamatsu R2949) through a spectrometer (Unisoku MD200). Sample solutions were deaerated by argon bubbling prior to the laser flash photolysis experiments.

\section{Measurement of the Fluorescence Switching Rate ${ }^{34}$}

Luminescence switching in the millisecond range was recorded using a laser flash photolysis apparatus. Excitation light (540 $\mathrm{nm}$ ) was provided by a Hamamatsu Light Source (LC8) combined with a long pass filter and $10 \mathrm{~nm}$ band-pass filter center at $540 \mathrm{~nm}$, coupled to fiber and a condenser to get a pseudocollimated light (diameter $6 \mathrm{~mm}, 5 \mathrm{~mW}$ ). Excitation pulses to switch the fluorescence $(355 \mathrm{~nm}$, fwhm $4 \mathrm{~ns}, 10 \mathrm{~mJ}, 0.5 \mathrm{~Hz}$ ) were provided by a $10 \mathrm{~Hz} \mathrm{Nd:YAG} \mathrm{laser} \mathrm{(Continuum} \mathrm{Surelite} \mathrm{II)} \mathrm{at} \mathrm{the} \mathrm{opposite}$ direction from the excitation source. The diameter of the excitation beam was about $8 \mathrm{~mm}$ to ensure that all the volume of collected emission was excited. The emitted light was collected at $90^{\circ}$, dispersed by a monochromator (Horiba Jobin-Yvon, iHR320), and analyzed with a photomultiplier (R1477-06, Hamamatsu) coupled to a digital oscilloscope (LeCroy 454, 500 MHz). Synchronization of excitation pulses and acquisition time was secured with a $\mathrm{PCl}-66028$ Channel counter/timer (National Instruments). The experiment was controlled by a homemade software written in LabView environment. The recorded traces were averaged for several pulses. A $1 \mathrm{~mm}$ (excitation, emission length) $\times 1 \mathrm{~cm}$ spectroscopic cell was used. Optical density (1 mm) of the solution at the excitation wavelength was below 0.1 to avoid any inner effect. The stability of the solution was checked after several excitations that fluorescence intensity keeps constant.

\section{Fluorescence Lifetime Mesurements}

\section{Fluorescence Microscopy}

The fluorescence microscopy was carried out with an Olympus BX51 microscope. The high-pressure mercury vapor lamp through a 540/10 nm band-pass filter was employed for the fluorescence excitation light. The stimulus light-inducing photochromism (365 and $405 \mathrm{~nm}, 200 \mathrm{~ms} /$ pulse) is performed with a Mosaic Digital Diaphragm System (Photonic Instruments, Inc.). The fluorescence of 1 and $\mathbf{2}$ were monitored with a Q IMAGING Scientific Digital CCD Camera (QI Click, exposure time; $15 \mathrm{ms)} \mathrm{through} \mathrm{a} \mathrm{632/10} \mathrm{nm}$ band-pass filter.

\section{Synthetic procedure}

All reactions were monitored by thin-layer chromatography carried out on $0.2 \mathrm{~mm}$ E. Merck silica gel plates (60F-254). Column chromatography was performed on silica gel (Silica gel 60N (spherical, neutral), 40-50 $\mathrm{mm}$, Kanto Chemical Co., Inc.). ${ }^{1} \mathrm{H}$ NMR 
spectra were recorded at $400 \mathrm{MHz}$ on a Bruker AVANCE III 400 NanoBay. DMSO- $d_{6}$ and $\mathrm{CDCl}_{3}$ and $\mathrm{CD}_{2} \mathrm{Cl}_{2}$ were used as deuterated solvent. MASS spectra (ESI-TOF-MS) were measured by using a Bruker micrOTOF II-AGA1. All glassware was washed with distilled water and dried. Unless otherwise noted, all reagents and reaction solvents were purchased-from Tokyo Chemical Industry Co., Ltd., Wako Pure Chemical Industries, Ltd., Sigma-Aldrich Inc. and Kanto Chemical Co., Inc. and were used without further purification.

Compound $\mathbf{3}^{46}$ and $\mathbf{8}^{47}$ were prepared according to a literature procedure.

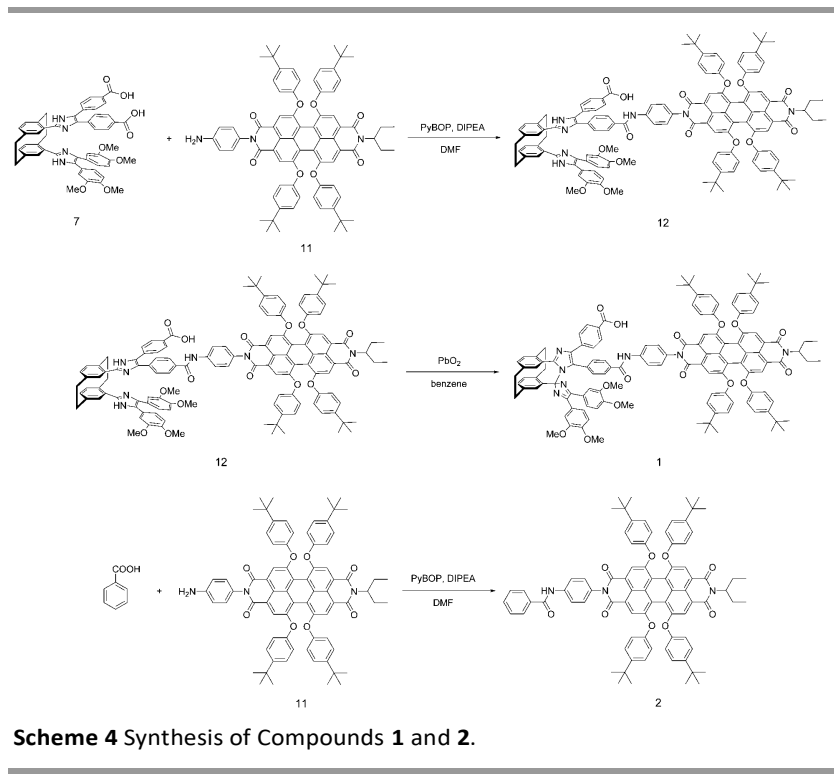

Compound 4. Compound 3 (400 mg, $1.34 \mathrm{mmol}$ ) and benzylbromide $(652 \mu \mathrm{L}, 5.46 \mathrm{mmol}$ ) were dissolved in acetonitrile $(8 \mathrm{~mL})$. The solution was added triethylamine $(760 \mu \mathrm{L})$ and refluxed for $22 \mathrm{~h}$. The organic layer was evaporated and the crude product was purified with silica gel column chromatography $\left(\mathrm{CHCl}_{3} /\right.$ hexane $\left.=1 / 1\right)$ to give the desired product as yellow solid. The product was recrystallized from $\mathrm{CH}_{2} \mathrm{Cl}_{2}$ /hexane to give yellow crystals $(554 \mathrm{mg}, 86 \%) .{ }^{1} \mathrm{H} \mathrm{NMR}\left(400 \mathrm{MHz}, \mathrm{CDCl}_{3}\right) \delta: 8.20(\mathrm{~d}, J=8.5$ $\mathrm{Hz}, 4 \mathrm{H}), 8.03(\mathrm{~d}, J=8.5 \mathrm{~Hz}, 4 \mathrm{H}), 7.45-7.34(\mathrm{~m}, 10 \mathrm{H}), 5.40(\mathrm{~s}, 4 \mathrm{H})$.

Compound 6. The reaction mixture of $5(120 \mathrm{mg}, 0.209 \mathrm{mmol}), 4(182 \mathrm{mg}, 0.380 \mathrm{mmol})$ and ammonium acetate (252 mg, $3.269 \mathrm{mmol}$ ) in $\mathrm{CH}_{2} \mathrm{Cl}_{2}$ was stirred for 2 days at $110{ }^{\circ} \mathrm{C}$ in the sealed tube. The reaction mixture was added water and the aqueous layer was extracted with $\mathrm{CH}_{2} \mathrm{Cl}_{2}$. The combined organic layer was washed with water and brine, dried over $\mathrm{Na}_{2} \mathrm{SO}_{4}$, filtered, and evaporated. The crude product was purified with silica gel column chromatography (hexane/AcOEt $=1 / 1$ ), to give the desired product as yellow solid (167 mg, 77\%). ${ }^{1} \mathrm{H}$ NMR $\left(400 \mathrm{MHz}, \mathrm{DMSO}-d_{6}\right) \delta: 11.92(\mathrm{~s}, 1 \mathrm{H}), 11.53(\mathrm{~s}, 1 \mathrm{H}), 7.68(\mathrm{t}, J=8.6 \mathrm{~Hz}, 4 \mathrm{H}), 7.50-$ $7.35(\mathrm{~m}, 11 \mathrm{H}), 7.32(\mathrm{~d}, J=8.4 \mathrm{~Hz}, 2 \mathrm{H}), 7.16-7.10(\mathrm{~m}, 4 \mathrm{H}), 6.98(\mathrm{~d}, J=8.2 \mathrm{~Hz}, 1 \mathrm{H}), 6.82-6.59(\mathrm{~m}, 8 \mathrm{H}), 5.38-5.33(\mathrm{~m}, 4 \mathrm{H}), 4.59-4.52$ $(\mathrm{m}, 2 \mathrm{H}), 3.62(\mathrm{~s}, 3 \mathrm{H}), 3.53(\mathrm{~s}, 3 \mathrm{H}), 3.42(\mathrm{~s}, 3 \mathrm{H}), 3.28(\mathrm{~s}, 3 \mathrm{H}), 3.16-3.07(\mathrm{~m}, 6 \mathrm{H})$.

Compound 7. Compound 6 ( $70 \mathrm{mg}, 0.0678 \mathrm{mmol}$ ) was dissolved in methanol and deoxygenated by $\mathrm{N}_{2}$ bubbling. After the addition of $\mathrm{Pd} / \mathrm{C}(280 \mathrm{mg})$, the solution was deoxygenated by $\mathrm{N}_{2}$ bubbling additionally. The mixture was stirred for $4 \mathrm{~h}$ under hydrogen atmosphere. The reaction mixture was filtered with celite and the filtrate was evaporated. The product was washed with dichloromethane to give the desired solid as yellow solid (44 mg, 76\%). ${ }^{1} \mathrm{H} \mathrm{NMR}\left(400 \mathrm{MHz}, \mathrm{DMSO}-d_{6}\right) \delta: 11.92(\mathrm{~s}, 1 \mathrm{H}), 11.62(\mathrm{~s}, 1 \mathrm{H})$, $7.63(\mathrm{t}, J=8.4 \mathrm{~Hz}, 4 \mathrm{H}), 7.31(\mathrm{~d}, J=8.0 \mathrm{~Hz}, 2 \mathrm{H}), 7.17(\mathrm{~d}, J=8.4 \mathrm{~Hz}, 2 \mathrm{H}), 7.11(\mathrm{~d}, J=8.0 \mathrm{~Hz}, 2 \mathrm{H}), 6.97(\mathrm{~d}, J=8.0 \mathrm{~Hz}, 1 \mathrm{H}), 6.85-6.60(\mathrm{~m}$, $9 \mathrm{H}), 4.60-4.55(\mathrm{~m}, 2 \mathrm{H}), 3.71(\mathrm{~s}, 3 \mathrm{H}), 3.64(\mathrm{~s}, 3 \mathrm{H}), 3.46(\mathrm{~s}, 3 \mathrm{H}), 3.15-3.03(\mathrm{~m}, 6 \mathrm{H})$.

Compound 9. A mixture of $8(2.03 \mathrm{~g}, 3.037 \mathrm{mmol})$, tert-butylphenol $(5.25 \mathrm{~g}, 34.95 \mathrm{mmol})$, potassium carbonate (5.68 $\mathrm{g}$, $41.09 \mathrm{mmol})$ and $\mathrm{N}$-methyl-2-pyrrolidone $(170 \mathrm{~mL})$ were stirred at $120^{\circ} \mathrm{C}$ during 20 hours. After the mixture was cooled to room temperature, the mixture was acidified with aqueous $3 \mathrm{~N} \mathrm{HCl}$ aq. $(100 \mathrm{~mL})$ and the mixture was stirred for additional 4 hours. The purple precipitated formed and was filtered under vacuum, thoroughly washed with water and dried for 12 hours in a vacuum oven to give purple solid $2.393 \mathrm{~g}(70 \%) .{ }^{1} \mathrm{H} \mathrm{NMR}\left(400 \mathrm{MHz}, \mathrm{CDCl}_{3}\right) \delta: 8.21(\mathrm{~s}, 4 \mathrm{H}), 7.22(\mathrm{~d}, J=8.8 \mathrm{~Hz}, 8 \mathrm{H}), 6.83(\mathrm{~d}, J=8.8 \mathrm{~Hz}, 8 \mathrm{H})$, 5.00-4.92 (m, 2H), 2.22-2.10 (m, 4H), 1.89-1.78 (m, 4H), $1.29(\mathrm{~s}, 36 \mathrm{H}), 0.85(\mathrm{t}, J=7.2 \mathrm{~Hz}, 12 \mathrm{H})$.

Compound 10. A mixture of $9(580 \mathrm{mg}, 0.516 \mathrm{mmol}), \mathrm{KOH}(98 \mathrm{mg}, 1.747 \mathrm{mmol})$ and $t$-BuOH $(24 \mathrm{~mL})$ was refluxed during 1.5 hours. After cooling down the mixture to room temperature, the mixture was acidified with acetic acid $(9 \mathrm{~mL})$ and $6 \mathrm{~N} \mathrm{HCl}$ aq. $(9 \mathrm{~mL})$. The precipitate was filtered, dried under vacuum and finally purified by $\mathrm{SiO}_{2}$ column chromatography $\left(\mathrm{CHCl}_{3} /\right.$ hexane $\left.=1 / 1\right)$, to give the desired product as purple solid $(110 \mathrm{mg}, 20 \%) .{ }^{1} \mathrm{H} \mathrm{NMR}\left(400 \mathrm{MHz}, \mathrm{CDCl}_{3}\right) \delta: 8.21(\mathrm{~s}, 2 \mathrm{H}), 8.20(\mathrm{~s}, 2 \mathrm{H}), 7.24(\mathrm{~d}, J=8.8 \mathrm{~Hz}$, 
$8 \mathrm{H}), 6.83(\mathrm{~d}, J=8.8 \mathrm{~Hz}, 4 \mathrm{H}), 6.82(\mathrm{~d}, J=8.8 \mathrm{~Hz}, 4 \mathrm{H}), 4.99-4.91(\mathrm{~m}, 1 \mathrm{H}), 2.21-2.12(\mathrm{~m}, 2 \mathrm{H}), 1.87-1.80(\mathrm{~m}, 2 \mathrm{H}), 1.29(\mathrm{~s}, 18 \mathrm{H}), 1.29(\mathrm{~s}$, $18 \mathrm{H}), 0.85(\mathrm{t}, J=7.4 \mathrm{~Hz}, 6 \mathrm{H})$.

Compound 11. A mixture of 10 (70 mg, $0.0664 \mathrm{mmol}), 1,4$-diaminobenzene (15 mg, $0.139 \mathrm{mmol}$ ) and imidazole (700 mg) was heated at $100^{\circ} \mathrm{C}$ for 5 hours. The crude mixture was cooled down to room temperature and acidified with $6 \mathrm{~N} \mathrm{HCl}$ aq. ( $7 \mathrm{~mL}$ ). The precipitate was filtered, dried under vacuum for $5 \mathrm{~h}$, and purified by $\mathrm{SiO}_{2}$ column chromatography (gradient, $\mathrm{CHCl}_{3}$ to $\left.\mathrm{CHCl}_{3}: \mathrm{EtOH}=1: 0.01\right)$, to give the desired product as purple solid $(49 \mathrm{mg}, 64 \%) .{ }^{1} \mathrm{H} \mathrm{NMR}\left(400 \mathrm{MHz}, \mathrm{CDCl}_{3}\right) \delta: 8.22(\mathrm{~s}, 2 \mathrm{H}), 8.21(\mathrm{~s}$, $2 \mathrm{H}), 7.24(\mathrm{~d}, J=8.8 \mathrm{~Hz}, 4 \mathrm{H}), 7.21(\mathrm{~d}, J=8.8 \mathrm{~Hz}, 4 \mathrm{H}), 6.99(\mathrm{~d}, J=8.8 \mathrm{~Hz}, 2 \mathrm{H}), 6.85(\mathrm{~d}, J=8.8 \mathrm{~Hz}, 4 \mathrm{H}), 6.82(\mathrm{~d}, J=8.8 \mathrm{~Hz}, 4 \mathrm{H}), 6.75(\mathrm{~d}$, $J=8.8 \mathrm{~Hz}, 2 \mathrm{H}), 4.99-4.93(\mathrm{~m}, 1 \mathrm{H}), 3.77(\mathrm{~s}, 2 \mathrm{H}), 2.22-2.11(\mathrm{~m}, 2 \mathrm{H}), 1.89-1.79(\mathrm{~m}, 2 \mathrm{H}), 1.28(\mathrm{~s}, 18 \mathrm{H}), 1.26(\mathrm{~s}, 18 \mathrm{H}), 0.86(\mathrm{t}, J=7.4 \mathrm{~Hz}$, $6 \mathrm{H})$.

Compound 12. A mixture of compound $7(70 \mathrm{mg}, 0.0821 \mathrm{mmol})$, benzotriazol-1-yl-oxytripyrrolidinophosphonium hexafluorophosphate (47 mg, $0.0903 \mathrm{mmol}$ ), DIPEA (45 mg, $0.348 \mathrm{mmol}$ ) and anhydrous DMF ( $8 \mathrm{~mL}$ ) were stirred for $1 \mathrm{~h} \mathrm{under}$ nitrogen atmosphere. Compound $11\left(93 \mathrm{mg}, 0.0813 \mathrm{mmol}\right.$ ) was then added and the mixture was stirred at $80^{\circ} \mathrm{C}$ during 2 days. The crude was acidified with an aqueous solution of $1 \mathrm{~N} \mathrm{HCl}(5 \mathrm{~mL})$ and extracted with $\mathrm{CHCl}_{3}$. The organic layer was washed with water and then evaporated. The obtained dark solid was purified by $\mathrm{SiO}_{2}$ column chromatography $(\mathrm{CHCl} 3: \mathrm{EtOH}=25: 1)$ and preparative thin layer chromatography $\left(\mathrm{CHCl}_{3}: \mathrm{EtOH}=25: 1\right)$ to give a purple solid as a mixture of two structural isomers (18 $\mathrm{mg}$, $11 \%) .{ }^{1} \mathrm{H}$ NMR (400 MHz, DMSO- $\left.d_{6}\right) \delta: 11.83(\mathrm{~s}, 1 \mathrm{H}$, one structural isomer), 11.69 (s, $1 \mathrm{H}$, one structural isomer), 11.68 (m, $2 \mathrm{H}, \mathrm{two}$ structural isomers), 7.96-7.93 ( $\mathrm{m}, 9 \mathrm{H}$, two structural isomers), 7.38-7.26 ( $\mathrm{m}, 30 \mathrm{H}$, two structural isomers), 7.20-6.98 (m, 39H, two structural isomers), $6.93(\mathrm{~s}, 9 \mathrm{H}$, one structural isomer), $6.91(\mathrm{~s}, 9 \mathrm{H}$, one structural isomer), $6.71(\mathrm{~d}, \mathrm{~J}=8.0 \mathrm{~Hz}, 4 \mathrm{H}$, two structural isomers), $6.63(\mathrm{t}, J=8.0 \mathrm{~Hz}, 4 \mathrm{H}$, two structural isomers), $4.89-4.79(\mathrm{~m}, 2 \mathrm{H}$, two structural isomers), $4.65-4.46$ (m, $4 \mathrm{H}$, two structural isomers), 3.15-3.02 (m, 12H, two structural isomers), 2.12-2.04 (m, 4H, two structural isomers), $1.81-1.72$ (m, 4H, two structural isomers), $1.27(\mathrm{~s}, 36 \mathrm{H}$, two structural isomers), $1.24(\mathrm{~m}, 36 \mathrm{H}$, two structural isomers), $0.78(\mathrm{t}, \mathrm{J}=8.0 \mathrm{~Hz}, 12 \mathrm{H}$, two structural isomers); ESI-TOF-MS: $m / z 1978[\mathrm{M}+\mathrm{H}]^{+}$.

Compound 1. All manipulations were carried out with the exclusion of light. Under nitrogen, to a solution of 12 (12 mg, $\left.6.06 \times 10^{-3} \mathrm{mmol}\right)$ in benzene $(2 \mathrm{~mL})$ was added $\mathrm{PbO}_{2}(16 \mathrm{mg}, 0.0669 \mathrm{mmol})$. The reaction mixture was vigorously stirred for $9 \mathrm{~h}$ at room temperature. The solution was filtered and the filtrate was evaporated. Then the crude product was separated by preparative thin layer chromatography using $\mathrm{CH}_{2} \mathrm{Cl}_{2}: \mathrm{MeOH}=20: 1$ as eluents to give the desired product as purple solid $(7 \mathrm{mg}, 58 \%) .{ }^{1} \mathrm{H} \mathrm{NMR}$ $\left(400 \mathrm{MHz}, \mathrm{CD}_{2} \mathrm{Cl}_{2}\right) \delta: 8.11(\mathrm{~s}, 2 \mathrm{H}), 8.03(\mathrm{~s}, 2 \mathrm{H}), 7.72-7.66(\mathrm{~m}, 5 \mathrm{H}), 7.57-7.46(\mathrm{~m}, 5 \mathrm{H}), 7.32-7.28(\mathrm{~m}, 4 \mathrm{H}), 7.22-7.15(\mathrm{~m}, 13 \mathrm{H}), 6.89$ $(\mathrm{s}, 1 \mathrm{H}), 6.83-6.73(\mathrm{~m}, 14 \mathrm{H}), 6.61-6.56(\mathrm{~m}, 4 \mathrm{H}), 6.44(\mathrm{~d}, J=8.0 \mathrm{~Hz}, 2 \mathrm{H}), 6.38(\mathrm{~d}, J=8.0 \mathrm{~Hz}, 2 \mathrm{H}), 4.89-4.82(\mathrm{~m}, 1 \mathrm{H}), 4.44-4.38(\mathrm{~m}$, $1 \mathrm{H}), 3.76(\mathrm{~s}, 3 \mathrm{H}), 3.65(\mathrm{~s}, 3 \mathrm{H}), 3.63(\mathrm{~s}, 3 \mathrm{H}), 3.60(\mathrm{~s}, 3 \mathrm{H}), 3.16-3.07(\mathrm{~m}, 5 \mathrm{H}), 3.00-2.86(\mathrm{~m}, 2 \mathrm{H}), 2.10-2.01(\mathrm{~m}, 2 \mathrm{H}), 1.77-1.70(\mathrm{~m}, 2 \mathrm{H})$, $1.23(\mathrm{~s}, 18 \mathrm{H}), 1.20(\mathrm{~s}, 18 \mathrm{H}), 0.76(\mathrm{t}, J=7.2 \mathrm{~Hz}, 12 \mathrm{H})$. ESI-TOF-MS: $\mathrm{m} / z 1976[\mathrm{M}+\mathrm{H}]^{+}$.

Compound 2. A mixture of benzoic acid $(10 \mathrm{mg}, 0.0819 \mathrm{mmol})$, benzotriazol-1-yl-oxytripyrrolidinophosphonium hexafluorophosphate (30 mg, $0.0576 \mathrm{mmol})$, DIPEA (19 mg, $0.147 \mathrm{mmol}$ ) and anhydrous DMF (1 mL) were stirred for $1 \mathrm{~h} \mathrm{under}$ nitrogen atmosphere. Compound 11 (40 mg, $0.0350 \mathrm{mmol}$ ) was then added and the mixture was stirred at $80{ }^{\circ} \mathrm{C}$ during 3 days. The crude was acidified with an aqueous solution of $3 \mathrm{~N} \mathrm{HCl}(8 \mathrm{~mL})$ and extracted with $\mathrm{CH}_{2} \mathrm{Cl}_{2}$. The organic layer was washed with water and brine, and then evaporated. The obtained dark solid was purified by preparative thin layer chromatography twice using $\mathrm{CHCl}_{3}: \mathrm{AcOEt}=25: 1$ and $\mathrm{CHCl}_{3}: \mathrm{MeOH}=100: 1$ as eluents to give the desired product as a purple solid $(20 \mathrm{mg}, 46 \%) .{ }^{1} \mathrm{H} \mathrm{NMR}(400$ $\left.\mathrm{MHz}, \mathrm{CDCl}_{3}\right) \delta: 8.24(\mathrm{~s}, 2 \mathrm{H}), 8.22(\mathrm{~s}, 2 \mathrm{H}), 7.89(\mathrm{~s}, 1 \mathrm{H}), 7.87(\mathrm{~s}, 3 \mathrm{H}), 7.80(\mathrm{~d}, J=8.8 \mathrm{~Hz}, 2 \mathrm{H}), 7.58-7.48(\mathrm{~m}, 4 \mathrm{H}), 7.24(\mathrm{~d}, J=8.8 \mathrm{~Hz}, 4 \mathrm{H})$, $7.21(\mathrm{~d}, J=8.8 \mathrm{~Hz}, 4 \mathrm{H}), 6.85(\mathrm{~d}, J=8.8 \mathrm{~Hz}, 4 \mathrm{H}), 6.83(\mathrm{~d}, J=8.8 \mathrm{~Hz}, 4 \mathrm{H}), 5.00-4.92(\mathrm{~m}, 1 \mathrm{H}), 2.22-2.11(\mathrm{~m}, 2 \mathrm{H}), 1.89-1.79(\mathrm{~m}, 2 \mathrm{H})$, $1.29(\mathrm{~s}, 18 \mathrm{H}), 1.26(\mathrm{~s}, 18 \mathrm{H}), 0.86(\mathrm{t}, J=7.4 \mathrm{~Hz}, 6 \mathrm{H})$.

\section{Conflicts of interest}

There are no conflicts to declare.

\section{Acknowledgements}

This work was supported partly by the Core Research for Evolutionary Science and Technology (CREST) program of the Japan Science and Technology Agency (JST) and JSPS KAKENHI Grant Number JP26107010 in Scientific Research on Innovative Areas "photosynergetics" and MEXT KAKENHI Grant Number JP17K1475 for K.M. This research is also conducted within the context of the International Associated Laboratory Nano-synergetics. M. S. acknowledge the financial support of the Agence National de la Recherche (ANR-14-CE08-0015-01 Ultrafast Nanoscopy).

\section{Notes and references}

1 P. Dedecker, F. C. De Schryver and J. Hofkens, J. Am. Chem. Soc., 2013, 135, 2387-2402. 
2 Y. Yabiku, S. Kubo, M. Nakagawa, M. Vacha and S. Habuchi, AlP Advances, 2013, 3, 102128.

3 J. T. King, C. Yu, W. L. Wilson and S. Granick, ACS Nano, 2014, 8, 8802-8809.

4 B. E. Urban, B. Dong, T.-Q. Nguyen, V. Backman, C. Sun and H. F. Zhang, Sci. Rep., 2016, 6, 28156.

5 T. Chen, B. Dong, K. Chen, F. Zhao, X. Cheng, C. Ma, S. Lee, P. Zhang, S. H. Kang, J. W. Ha, W. Xu and N. Fang, Chem. Rev., 2017, 117, 7510-7537.

6 A. Miyawaki, Neuron, 2005, 48, 189-199.

7 F. Helmchen and W. Denk, Curr. Opin. Neurobiol., 2002, 12, 593-601.

8 T. Ueno, Y. Urano, K. Setsukinai, H. Takakusa, H. Kojima, K. Kikuchi, K. Ohkubo, S. Fukuzumi and T. Nagano, J. Am. Chem. Soc., 2004, 126, 14079-14085.

9 E. Sakaki, H. Kojima, H. Nishimatsu, Y. Urano, K. Kikuchi, Y. Hirata and T. Nagano, J. Am. Chem. Soc., 2005, 127, 3684-3685.

10 H.-Y. Ahn, K. E. Fairfull-Smith, B. J. Morrow, V. Lussini, B. Kim, M. V. Bondar, S. E. Bottle and K. D. Belfield, J. Am. Chem. Soc., 2012, 134, 4721-4730.

11 T. A. Klar, S. Jakobs, M. Dyba, A. Egner and S. W. Hell, Proc. Natl. Acad. Sci. U.S.A., 2000, 97, 8206-8210.

12 S. W. Hell, Science, 2007, 316, 1153-1158.

13 P. Dedecker, J. Hotta, C. Flors, M. Sliwa, H. Uji-i, M. B. J. Roeffaers, R. Ando, H. Mizuno, A. Miyawaki and J. Hofkens, J. Am. Chem. Soc., 2007, 129, 16132-16141.

14 T. Brakemann, A. C. Stiel, G. Weber, M. Andresen, I. Testa, T. Grotjohann, M. Leutenegger, U. Plessmann, H. Urlaub, C. Eggeling, M. C. Wahl, S. W. Hell and S. Jakobs, Nature Biotechnol., 2011, 29, 942-947.

15 S. T. Hess, T. P. K. Girirajan and M. D. Mason, Biophys. J., 2006, 91, 4258-4272.

16 E. Betzig, G. H. Patterson, R. Sougrat, O. W. Lindwasser, S. Olenych, J. S. Bonifacino, M. W. Davidson, J. Lippincott-Schwartz and H. F. Hess, Science, 2006, 313, 1642-1645.

17 M. J. Rust, M. Bates, X. Zhuang, Nature Meth., 2006, 3, 793-796.

18 M. Fernández-Suárez and A. Y. Ting, Nat. Rev. Mol. Cell Biol., 2008, 9, 929-943.

19 M. Sauer and M. Heilemann, Chem. Rev., 2017, 117, 7478-7509.

20 F. Balzarotti, Y. Eilers, K. C. Gwosch, A. H. Gynna, V. Westphal, F. D. Stefani, J. Elf and S. W. Hell, Science, 355, 606-612.

21 T. Dertinger, R. Colyer, G. Iyer, S. Weiss and J. Enderlein, Proc. Natl. Acad. Sci. U.S.A., 2009. 106, $22287-22292$.

22 J. C. Crano and R. J. Guglielmetti, Organic Photochromic and Thermochromic Compounds, Plenum Press, New York, 1999.

23 H. Duerr and H. Bouas-Laurent, Photochromism: Molecules and Systems, Elsevier, Amsterdam, 2003.

24 M. Irie, T. Fukaminato, K. Matsuda and S. Kobatake, Chem. Rev., 2014, 114, 12174-12277.

25 Y. Yu, M. Nakano and T. Ikeda, Nature, 2003, 425, 145.

26 S. Kobatake, S. Takami, H. Muto, T. Ishikawa and M. Irie, Nature, 2007, 446, 778-781.

27 K. Matsuda and M. Irie, Chem. Lett., 2000, 29, 16-17.

28 T. Fukaminato, M. Tanaka, T. Doi, N. Tamaoki, T. Katayama, A. Mallick, Y. Ishibashi, H. Miyasaka and M. Irie, Photochem. Photobiol. Sci., 2010, 9, 181-187.

29 E. Deniz, M. Tomasulo, J. Cusido, S. Sortino and F. M. Raymo, Langmuir, 2011, 27, 11773-11783.

30 K. Uno, H. Niikura, M. Morimoto, Y. Ishibashi, H. Miyasaka and M. Irie, J. Am. Chem. Soc., 2011, 133, 13558-13564.

31 E. Deniz, M. Tomasulo, J. Cusido, I. Yildiz, M. Petriella, M. L. Bossi, S. Sortino and F. M. Raymo, J. Phys. Chem. C, 2012, 116, 60586068.

32 J. Su, T. Fukaminato, J.-P. Placial, T. Onodera, R. Suzuki, H. Oikawa, A. Brosseau, F. Brisset, R. Pansu, K. Nakatani and R. Métivier, Angew. Chem. Int. Ed., 2016, 55, 3662-3666.

33 Y. Kishimoto and J. Abe, J. Am. Chem. Soc., 2009, 131, 4227-4229.

34 K. Mutoh, M. Sliwa and J. Abe, J. Phys. Chem. C, 2013, 117, 4808-4814.

35 W.-L. Gong, J. Yan, L.-X. Zhao, C. Li, Z.-L. Huang, B. Z. Tang and M.-Q. Zhu, Photochem. Photobiol. Sci., 2016, 15, 1433-1441.

36 Q.-X. Hua, B. Xin, Z.-J. Xiong, W.-L. Gong, C. Li, Z.-L. Huang and M.-Q. Zhu, Chem. Commun., 2017, 53, $2669-2672$.

37 T. Weil, T. Vosch, J. Hofkens, K. Peneva and K. Müllen, Angew. Chem. Int. Ed., 2010, 49, 9068-9093

38 K. Mutoh and J. Abe, J. Phys. Chem. A, 2011, 115, 4650-4656.

39 D. Magde, J. H. Brannon, T. L. Cremers and J. Olmsted, J. Phys. Chem., 1979, 83, 696-699.

40 D. F. Eaton, Pure Apply. Chem., 1988, 60, 1107-1114.

41 E. Fron, G. Schweitzer, P. Osswald, F. Würthner, P. Marsal, D. Beljonne, K. Müllen, F. C. De Schryver and M. Van der Auweraer, Photochem. Photobiol. Sci., 2008, 7, 1509-1521.

42 B. Debus, M. Sliwa, H. Miyasaka, J. Abe and C. Ruckebusch, Chemom. Intell. Lab. Syst., 2013, 128, $101-110$.

43 K. Mutoh, E. Nakano, J. Abe, J. Phys. Chem. A, 2012, 116, 6792-6797.

44 K. Ouhenia-Ouadahi, R. Métivier, S. Maisonneuve, A. Jacquart, J. Xie, A. Léaustic, P. Yu and K. Nakatani, Photochem. Photobiol. Sci., 2012, 11, 1705-1714

45 N. Ishii and J. Abe, Appl. Phys. Lett., 2013, 102, 163301.

46 Q. Miao, J. Gao, Z. Wang, H. Yu, Y. Luo and T. Ma, Inorg. Chim. Acta, 2011, 376, 619-627.

47 K. Mahata, P. D. Frischmann and F. Würthner, J. Am. Chem. Soc., 2013, 135, 15656-15661. 